\title{
Subclass responses and their half-lives for antibodies against EBA175 and PfRh2 in naturally acquired immunity against Plasmodium falciparum malaria
}

Hodan Ahmed Ismail ${ }^{1}$, Muyideen K Tijani ${ }^{1,2 \dagger}$, Christine Langer $^{3}$, Linda Reiling ${ }^{3}$, Michael T White ${ }^{4}$, James G Beeson ${ }^{3}$, Mats Wahlgren ${ }^{1}$, Roseangela Nwuba ${ }^{2}$ and Kristina EM Persson ${ }^{1,5^{*}}$

\begin{abstract}
Background: Plasmodium falciparum EBA175 and PfRh2 belong to two main families involved in parasite invasion, and both are potential vaccine candidates. Current knowledge is limited regarding which target antigens and subclasses of antibodies are actually important for protection, and how naturally acquired immunity is achieved.

Methods: Repeated blood samples were collected from individuals in Nigeria over a period of almost one year. ELISA was used to analyse subclasses of IgG responses.

Results: For both EBA175 (region III-V) and (a fragment of) PfRh2, the dominant antibody responses consisted of $\operatorname{lgG1}$ and IgG3 followed by lgG2, while for PfRh2 there was also a relatively prominent response for lgG4. High levels of $\lg G 1, \lg G 2$ and $\lg G 3$ for EBA175 and total IgG for PfRh2 correlated significantly with a lower parasitaemia during the study period. Children with HbAS had higher levels of some subclasses compared to children with HbAA, while in adults the pattern was the opposite. The half-lives of $\operatorname{lgG} 2$ and $\operatorname{lgG} 4$ against EBA175 were clearly shorter than those for $\lg \mathrm{G} 1$ and $\lg \mathrm{G} 3$.

Conclusion: EBA175 and PfRh2 are potential targets for protective antibodies since both correlated with lower parasitaemia. The shorter half-lives for lgG2 and lgG4 might explain why these subclasses are often considered less important in protection against malaria. Triggering the right subclass responses could be of critical importance in a successful vaccine. Further studies are needed to evaluate the role of haemoglobin polymorphisms and their malaria protective effects in this process.
\end{abstract}

Keywords: Plasmodium falciparum, Malaria, EBA175, PfRh2, Merozoite, IgG, Subclass, Antibody, HbAA, HbAS

\section{Background}

The protozoa Plasmodium falciparum still remains a major global health problem. It is a leading cause of death among children under the age of five and pregnant women in sub-Saharan Africa [1,2]. The increasing problem of drug resistance and the limited effect of vector

\footnotetext{
* Correspondence: kristina.persson@med.lu.se

${ }^{\dagger}$ Equal contributors

'Department of Microbiology, Tumor and Cell Biology (MTC), Karolinska Institutet, Nobels väg 16, 17177 Stockholm, Sweden

${ }^{5}$ Department of Laboratory Medicine, Lund University, University Hospital, Lund, Sweden

Full list of author information is available at the end of the article
}

control interventions make a call for a malaria vaccine urgent [3].

The $P$. falciparum blood stage invasion involves many complex interactions between merozoite antigens and erythrocyte receptors. There are two main merozoite invasion families: erythrocyte binding-like (EBL) proteins and reticulocyte binding protein homologue (RBP/PfRh) proteins $[4,5]$. The EBL proteins include the erythrocyte binding antigens (EBAs), which are found in the micronemes of the merozoite and include EBA140, EBA175 and EBA181. The PfRh proteins are located in the 
rhoptries of the merozoites and include PfRh1, PfRh2a/ 2b, PfRh4, and PfRh5 [4-8]. PfRh2a and PfRh2b share the same amino acids for the first $88 \%$ of the protein [9]. EBA175 and PfRh2 are representatives of the sialic aciddependent and non-sialic acid-dependent invasion pathways, respectively $[10,11]$, and both are potential vaccine candidates. EBA175 binds to glycophorin A on the erythrocyte surface [4], but the receptor for PfRh2 is not yet known.

Acquired immunity to malaria develops only after repeated exposure in individuals living in endemic areas, and it has been suggested that young children are less able to induce long-lived antibody secreting cells [12-15]. However, it seems that some antibodies, such as those against MSP1, can have a half-life that spans over many years [16]. It is known that antibodies are an important component of acquired immunity, and it has been shown that passive transfer of antibodies from immune donors to individuals with $P$. falciparum infections reduced parasitaemia and clinical symptoms [17]. Antibodies against several merozoite antigens, including EBAs and PfRhs, have been shown to be associated with protection against malaria in prospective longitudinal studies [13,18-21]. Cytophilic immunoglobulins, IgG1 and IgG3 have been considered more important for protection as non-cytophilic IgG2 and IgG4 may block the protective activity of the cytophilic antibodies [20-25]. IgG1 and IgG3 are believed to neutralize parasites directly by inhibiting the parasite, or indirectly by opsonization [24-27].

There are several genetic polymorphisms that have been described to be protective against the severe forms of malaria, and one of these is sickle haemoglobin $(\mathrm{HbS})$, of which there is a high prevalence in sub-Saharan Africa [28-30]. In the homozygous form it can be deleterious to the individual, but protective against malaria in the heterozygous form (HbAS), as described over 60 years ago [31]. Since then, several studies have shown the protective effects of HbAS on malaria [30,32,33]. A recent metaanalyses study of children with HbAS showed more than $90 \%$ protection from severe malaria [33]. Other studies have shown HbAS to give $30-50 \%$ protection from uncomplicated malaria [30,33-36]. The mechanism behind the protective effect is still unclear, but it probably involves both the impaired development of the parasite inside the erythrocyte and a better immunological response, and it has also been suggested that a mechanism of impaired cytoadherence could be of importance [37].

In this study, naturally acquired antibody responses, total IgG as well as IgG subclasses, were investigated against EBA175 and PfRh2, as representatives of two different invasion pathways. Combinations of the two antigens together have been suggested to be more effective as vaccines, compared to using individual antigens [38]. Furthermore, associations between different haemoglobin genotypes and the presence of acquired antibodies against these antigens were investigated. Samples used were collected at least once a month from children and adults living in Igbo-Ora, a rural area of Nigeria, over a period of almost one year. Very few studies have looked at immunoglobulin subclass responses and the half-lives of the antibodies directed against these antigens, but this knowledge is important to evaluate the effect of using merozoite antigens as vaccines [19,39-42].

\section{Methods}

\section{Study area and participants}

A longitudinal study was conducted in Igbo-Ora, a rural town in Nigeria. Malaria is endemic with higher transmission during the rainy season (April to October) with a mean seasonal entomological inoculation rate (EIR) of 131 [43]. Individuals (200) between five and 70 years old were enrolled in the study from July 2009 to July 2010. Venous blood samples were collected at baseline for blood group typing, blood genotyping and immunological studies. Thick and thin smears were made for parasitological investigations. The participants were followed up clinically and parasitologically at least once a month for a period of eight months. Only participants who were permanent residents were included in the study. Pregnant women, children under the age of five, and those with signs of severe hepatic or renal dysfunction, sickle cell disease, G6PD or seropositivity for HIV were excluded. Participants who fell ill with malaria were treated with oral artemisinin-lumefantrine for clinical malaria and blood films were monitored until negative. Children diagnosed for severe malaria were admitted to hospital and treated with i/v quinine according to WHO recommendations. Written informed consent by adult participants or parent/guardian was received, and ethical permissions were granted for the study from University of Ibadan and Ethics Committee in Nigeria (UI/IRC/06/0038) and the Stockholm Ethical Review Board (2013/4:8). From the original 200 individuals that were recruited for the longitutinal study, 40 were randomly selected to be used in this study, with a total of 302 samples used. Eighteen of the individuals were children (aged five to 13 years, 17 were parasite positive at some stage during the eight-month sample collection time) and 22 were adults (21 were parasite positive).

\section{Recombinant proteins}

The recombinant merozoite antigens used in this study have been described in detail previously [44]. In brief, regions III to V of EBA175 (3D7; aa 761 to 1298) [19] and PfRh2A9 (3D7; aa 2027 to 2533, common region for both PfRh2a and PfRh2b) [42] were expressed in E. coli as GSTtagged fusion proteins. 


\section{Measuring total lgG and subclasses against recombinant antigens}

Enyme-linked immunosorbent assay (ELISA) for total IgG against EBA175 and PfRh2A9 were performed as described previously [41]. The antibody reactivity against subclasses IgG1-IgG4 was measured as follows: Flat bottom, 96-well plates (Nunc-immunoplate, Thermo Scientific) were coated with $1 \mu \mathrm{g} / \mathrm{ml}$ recombinant antigen in coating buffer $\left(15 \mathrm{mM} \mathrm{Na}_{2} \mathrm{CO}_{3}\right.$ and $35 \mathrm{mM} \mathrm{NaHCO}_{3}$; $\mathrm{pH}$ 9.6), washed $3 \mathrm{x}$ with PBS Tween 20 (PBS with $0.05 \%$ v/v Tween 20), blocked with $10 \%$ skimmed milk (SigmaAldrich M7409) in PBS-Tween 20 and washed 3x. Plasma samples diluted in 5\% skimmed milk PBS-Tween 20 (1:25) were incubated for 1.5 hours $\left(37^{\circ} \mathrm{C}\right)$, washed $3 \mathrm{x}$, and mouse anti human antibodies were added (IgG1 A10630, IgG2 05-3500, IgG3 05-3600, IgG4 A10651 (all from Invitrogen Corp, CA, USA)) and diluted in 5\% skimmed milk in PBS-Tween 20 (1/500 for IgG1 and IgG3, and 1/250 for IgG2 and IgG4, dilutions chosen after optimization) and incubated for 1.5 hours at $37^{\circ} \mathrm{C}$. After washing (3x) goat anti-mouse IgG $(\mathrm{H}+\mathrm{L})$ horseradish peroxidase (HRP) (G21040, Invitrogen Corp, CA, USA) was added at 1/500 for IgG1 and IgG3, and at $1 / 1,000$ for IgG2 and IgG4, incubated for 1.5 hours at $37^{\circ} \mathrm{C}$, washed $3 \mathrm{x}$ and antibody reactivity was detected with azino-bis(3-ethylbenthiazoline-6-sulfonic acid) (ABTS) tablet (Sigma Aldrich) dissolved in phosphate citrate buffer pH 5.0 (Sigma Aldrich); $30 \% \mathrm{H}_{2} \mathrm{O}_{2}$ was added just before use. Plates were incubated at room temperature for 1 hour and optical density (OD) read at $414 \mathrm{~nm}$. All assays were run in duplicate and OD was subtracted for non-specific binding of the fusion tag, GST. Positive (pools of immune samples) and negative (Swedish non-immune) controls were included on all plates to allow for standardization. Non-immune samples gave OD values below 0.06. Antibody reactivity was considered positive when the absorbance was greater than the mean plus three standard deviations of the value for the non-immune Swedish samples.

\section{Statistical analyses}

Data analyses were performed using GraphPad Prism Version 5.0a software. Antibody levels were compared by using Mann-Whitney t-test or ANOVA. The Spearman rank correlation was used to assess the association between two continuous variables. Two-tailed P-values were considered significant if they were $<0.05$. Data analyses were performed on data from time point follow-up during the study period. Antibody levels and subsequent levels of parasitaemia over the whole study period were analysed.

Under the assumption that antibodies decay at a constant rate, the half-lives of antibody decay were estimated for individuals where decreasing antibody levels were observed for at least three consecutive samples.
The rate of antibody decay and half-life was estimated via linear regression of log antibody titre against the time of sampling.

\section{Results}

Total IgG and IgG subclass responses to EBA175 and PfRh2

IgG and subclass responses to the recombinant merozoite antigens EBA175 and PfRh2, were measured by ELISA. For EBA175, the total IgG levels in the study group increased from August with peak in November (followed by decline in the following months (Figure 1). The IgG levels for PfRh2 showed a similar pattern, and when the different subclass responses (IgG1-4) for both EBA175 and PfRh2 were studied, the fluctuations over time were similar to the values for total IgG. All patterns were also similar whether children or adults were investigated separately or together. All 40 individuals included were tested between seven and eight times during the study period. All individuals (100\%) had IgG antibodies against EBA175 and PfRh2 at some stage during the eight months of follow-up (Table 1).

When the subclass responses were studied, it was noted that for both EBA175 and PfRh2 the response was dominated by the cytophilic IgG1 and IgG3, but there was also some IgG2 response (Figure 2). For PfRh2 there was also a relatively strong response for IgG4. When the values were correlated to each other, it was found that total IgG levels against EBA175 and PfRh2 showed a weak to moderate, but significant positive correlation with each other $\left(R^{2}=0.22, p=0.0002\right)$, and this was also

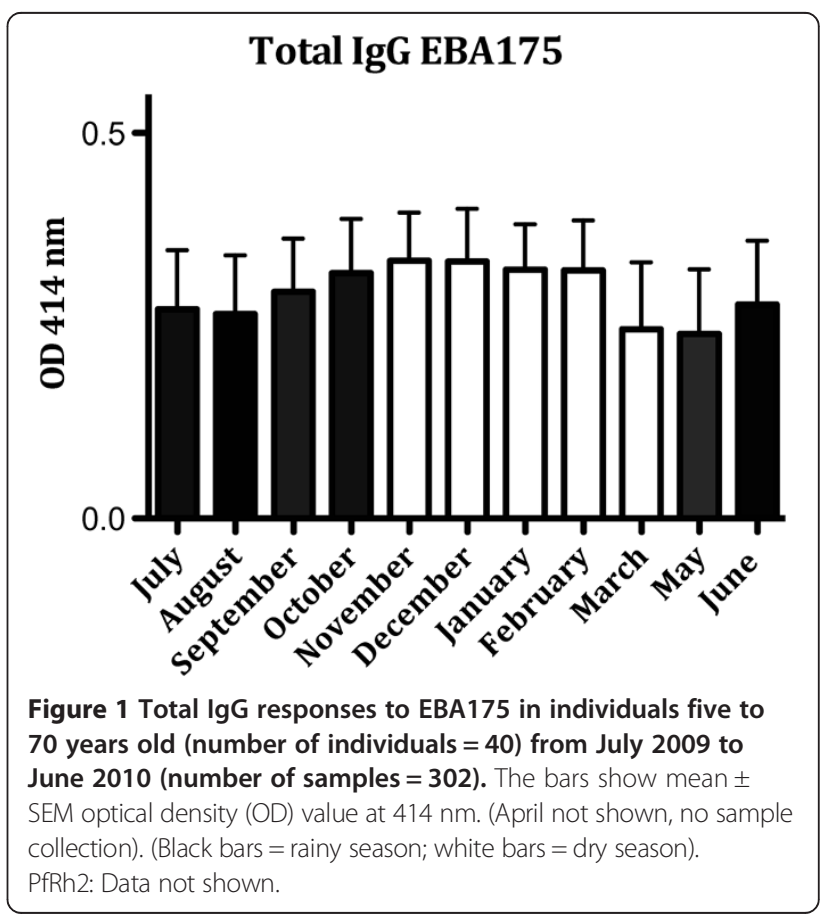


Table 1 The prevalence of antibodies against EBA175 and PfRh2 during the study period

\begin{tabular}{|c|c|c|c|c|}
\hline \multirow{2}{*}{$\begin{array}{l}\text { Prevalence } \\
(\%)^{\mathrm{a}}\end{array}$} & \multicolumn{3}{|c|}{ PfRh2 } & \multirow{2}{*}{$\begin{array}{l}\text { EBA175 } \\
\text { 14-70 years } \\
\text { ( } 22 \text { adults) }\end{array}$} \\
\hline & $\begin{array}{l}\text { 5-13 years } \\
\text { (18 children) }\end{array}$ & $\begin{array}{l}14-70 \text { years } \\
\text { ( } 22 \text { adults) }\end{array}$ & $\begin{array}{l}\text { 5-13 years } \\
\text { (18 children) }\end{array}$ & \\
\hline Total IgG & $100 \%$ & $100 \%$ & $100 \%$ & $100 \%$ \\
\hline $\lg \mathrm{G} 1$ & $83 \%$ & $95 \%$ & $94 \%$ & $82 \%$ \\
\hline $\lg \mathrm{g} 2$ & $86 \%$ & $86 \%$ & $94 \%$ & $82 \%$ \\
\hline $\operatorname{lgG} 3$ & $83 \%$ & $77 \%$ & $94 \%$ & $91 \%$ \\
\hline $\operatorname{lgG} 4$ & $89 \%$ & $77 \%$ & $94 \%$ & $95 \%$ \\
\hline
\end{tabular}

$\mathrm{a}=$ Positive prevalence when antibody titers (OD) were greater than the mean plus $3 \mathrm{SD}$ of the value for the non-immune Swedish donors.
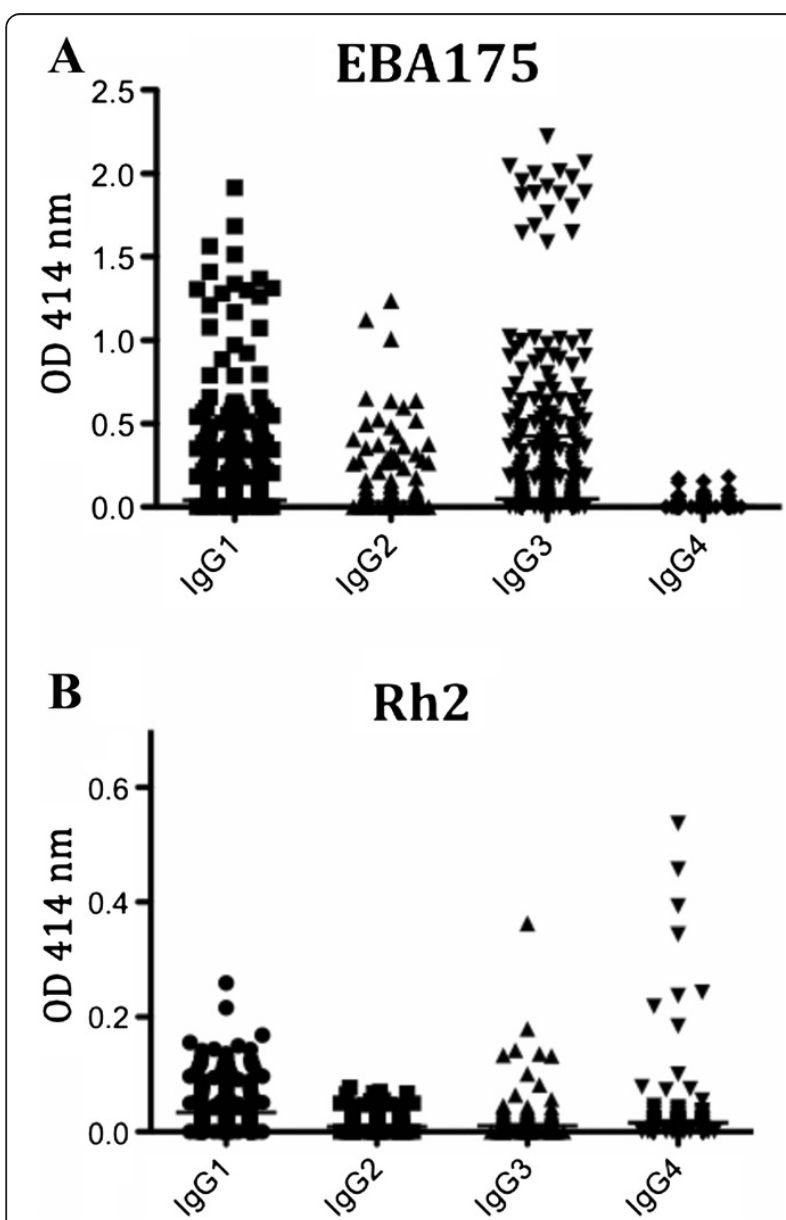

Figure 2 lgG subclass responses to Plasmodium falciparum merozoite antigens (A) EBA175 and (B) PfRh2 in individuals five to 70 years old, followed over almost one year. The scatter plot shows mean \pm SEM OD for values at $414 \mathrm{~nm}$; all samples $(n=302)$ from all individuals $(n=40)$ are included. noted for the IgG1 levels $\left(R^{2}=0.25\right.$ and $\left.p<0.0001\right)$, indicating co-acquisition of different antibodies with malaria exposure. No significant correlations were observed in IgG2, IgG3 or IgG4 between EBA175 and PfRh2 OD values (IgG2, $R^{2}=0.1$ and $p=0.1 ; \operatorname{IgG} 3, R^{2}=0.05$ and $p=0.4$; IgG4, $R^{2}=0.02$ and $p=0.7$ ). Furthermore, when the total IgG and subclass responses within EBA175 and PfRh2 were investigated it was observed that there were good correlations for EBA175, but less so for PfRh2 (Table 2).

When male and female subjects were analysed separately, samples from females showed slightly higher values for total $\operatorname{IgG}(\mathrm{p}=0.0025), \operatorname{IgG} 3(\mathrm{p}=0.04)$ and IgG4 $(\mathrm{p}=0.03)$ for EBA175, and $\operatorname{IgG} 2(\mathrm{p}=0.02)$ and IgG4 $(\mathrm{p}=0.006)$ for PfRh2. Male individuals showed higher values only for IgG1 EBA175 ( $\mathrm{p}=0.03)$.

Table 2 Correlations of total IgG and subclass IgG1-IgG4 responses against EBA175 and PfRh2

\begin{tabular}{|c|c|c|}
\hline Antigen-IgG & Spearman $r$ & $p$-value \\
\hline \multicolumn{3}{|c|}{ EBA175 Total lgG vs } \\
\hline $\lg \mathrm{I} 1$ & 0.57 & $<0.0001$ \\
\hline $\lg G 2$ & 0.46 & $<0.0001$ \\
\hline $\operatorname{lgG} 3$ & 0.49 & $<0.0001$ \\
\hline $\operatorname{lgG} 4$ & 0.38 & $<0.0001$ \\
\hline \multicolumn{3}{|c|}{ EBA175 lgG1 vs } \\
\hline $\lg G 2$ & 0.5 & $<0.0001$ \\
\hline $\operatorname{lgG} 3$ & 0.63 & $<0.0001$ \\
\hline $\operatorname{lgG4}$ & 0.25 & $<0.0001$ \\
\hline \multicolumn{3}{|c|}{ EBA $175 \operatorname{lgG} 2$ vs } \\
\hline $\operatorname{lgG} 3$ & 0.48 & $<0.0001$ \\
\hline $\operatorname{lgG4}$ & 0.40 & $<0.0001$ \\
\hline \multicolumn{3}{|c|}{ EBA175 lgG3 vs } \\
\hline $\operatorname{lgG4}$ & 0.34 & $<0.0001$ \\
\hline \multicolumn{3}{|c|}{ Rh2 Total lgG vs } \\
\hline $\lg \mathrm{I} 1$ & 0.55 & $<0.0001$ \\
\hline $\lg G 2$ & 0.07 & 0.26 \\
\hline $\operatorname{lgG} 3$ & 0.04 & 0.48 \\
\hline $\operatorname{lgG} 4$ & 0.1 & 0.08 \\
\hline \multicolumn{3}{|l|}{ Rh2 IgG1 vs } \\
\hline $\lg G 2$ & 0.07 & 0.23 \\
\hline $\operatorname{lgG} 3$ & 0.09 & 0.13 \\
\hline $\operatorname{lgG4}$ & 0.1 & 0.07 \\
\hline \multicolumn{3}{|l|}{$\mathrm{Rh} 2 \lg G 2$ vs } \\
\hline $\lg G 3$ & 0.27 & $<0.0001$ \\
\hline $\operatorname{lgG} 4$ & 0.21 & 0.004 \\
\hline \multicolumn{3}{|l|}{ Rh2 lgG3 vs } \\
\hline $\operatorname{lgG} 4$ & -0.05 & 0.35 \\
\hline
\end{tabular}




\section{Correlation of antibody responses with age}

When age was correlated to the levels of antibodies, it was found that there were significant positive correlations with total $\operatorname{IgG}\left(R^{2}=0.12\right.$ and $\left.p=0.036\right), \operatorname{IgG} 1\left(R^{2}=0.29\right.$ and $p=<0.0001)$ and $\operatorname{IgG3}\left(R^{2}=0.33\right.$ and $\left.p<0.0001\right)$ for EBA175. IgG2 and IgG4 against EBA175 did not show any correlations with age (IgG2, $R^{2}=0.01, \mathrm{p}=0.8 ; \operatorname{IgG} 4, R^{2}=$ $0.03, \mathrm{p}=0.6)$. There were no significant correlations between age and levels of antibodies against PfRh2 ( $p$-values 0.3-0.8).

\section{Correlation of antibody responses with parasitaemia}

The parasitaemia in the study group was monitored during the whole study period. The highest peak in parasitaemia was observed in the month of October (mean: 749.7 parasites $/ \mu \mathrm{l})$, while the lowest number was seen in May (mean: 3.7 parasites/ $\mu \mathrm{l}$ ) (Figure 3). There was no significant difference in parasitaemia between children (5-13 years) and adults (14-70 years) $(\mathrm{p}=0.3)$.

To assess whether the antibody responses in this study group were associated with protection, the relationship between antibody levels and parasitaemia was investigated. Higher IgG1, IgG2 and IgG3 levels for EBA175 and total IgG for PfRh2 correlated significantly with lower parasitaemia $\left(R^{2}=0.19, p=0.002 ; R^{2}=0.19, p=0.002 ; R^{2}=0.21\right.$, $p=0.0008 ; R^{2}=0.24, p<0.0001$, respectively). There were no significant differences between IgG levels measured before and after an episode of parasitemia (not shown).

Additionally, individuals with the highest quartiles of levels of total IgG against EBA175 or PfRh2 showed an even higher correlation with reduction of parasitaemia (EBA175, $R^{2}=0.54, p<0.0001$; PfRh2, $R^{2}=0.42, p=0.002$,

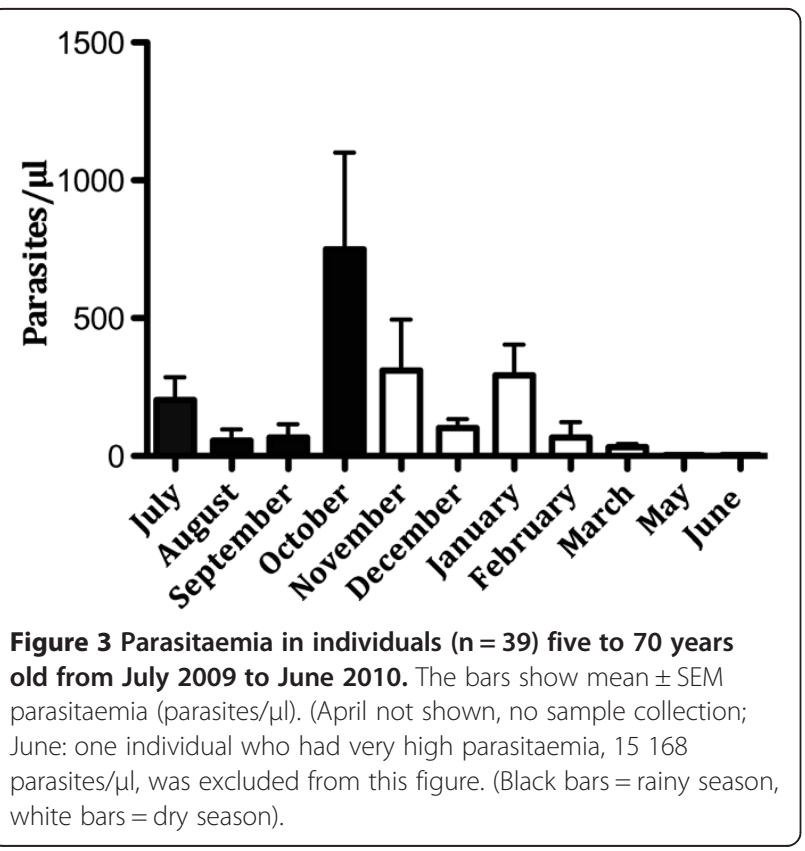

Spearman rank correlation comparing levels of antibodies with parasitaemia for every sample), and when individuals with high total levels of both antibodies against EBA175 and PfRh2 were considered (number of individuals $=11$, number of samples $=78$ ) they had a lower parasitaemia compared to those with raised levels of only one of the antibodies $(p=0.03)$.

\section{The impact of $\mathrm{HbAA}$ and $\mathrm{HbAS}$ carriage on the levels of IgG}

Out of the 40 patients included in this study, 30 had HbAA (normal, adult haemoglobin), nine had HbAS and one had HbAC. There was no significant difference in parasitaemia or age between the HbAA and HbAS groups ( $\mathrm{p}=0.27$ and 0.32 , respectively).

When all individuals were considered together, total IgG, IgG1 and IgG3 against EBA175 were significantly higher in individuals with $\mathrm{HbAA}$ compared to $\mathrm{HbAS}$ (IgG, $p=0.008$; IgG1, $p=0.048$; IgG3, $p=0.0001$ ). For PfRh2, only the IgG1 response was significantly higher in $\mathrm{HbAA}$ $(p=0.0001)$.

When the samples where divided into the two groups children $(n=18$, age 5-13) and adults $(n=21$, age 14-70), children with HbAS had significantly higher levels of IgG, IgG1, IgG2, and IgG3 against EBA175 and higher levels of IgG against PfRh2 compared to HbAA (Figure 4). When adults were considered, the pattern was the opposite with higher levels of IgG, IgG1 and IgG3 against EBA175 in HbAA individuals (there were no significant differences for PfRh2).

\section{Comparison of half-lives of total lgG and subclasses}

For EBA175, IgG2 and IgG4 showed significantly shorter half-lives compared to IgG1 ( $p<0.05 /<0.01)$, to IgG3 ( $p<0.05 /<0.01$ ), and to total IgG ( $p<0.01$ for both) (Figure 5). For PfRh2, a similar trend was seen as for EBA175, but the only significant differences seen were those that showed shorter half-lives for IgG1, IgG2 and IgG4 compared to total IgG, and a shorter half-life for IgG4 compared to IgG1 ( $\mathrm{p}<0.05$ for all comparisons). There were no significant associations between half-lives and ages of the tested individuals.

For total IgG, half-lives of parasite positive and parasite negative individuals were compared. For EBA175, the period of antibody decay was 98 days for parasite positive individuals and 64 days for parasite negative individuals. For PfRh2, the half-life was 120 days for parasite positive and 82 days for parasite negative individuals. However, due to the small number of parasite negative individuals, it is difficult to estimate the value of these differences.

\section{Discussion}

In this study, total IgG and subclass responses against EBA175 and PfRh2 were investigated, and the effects of 

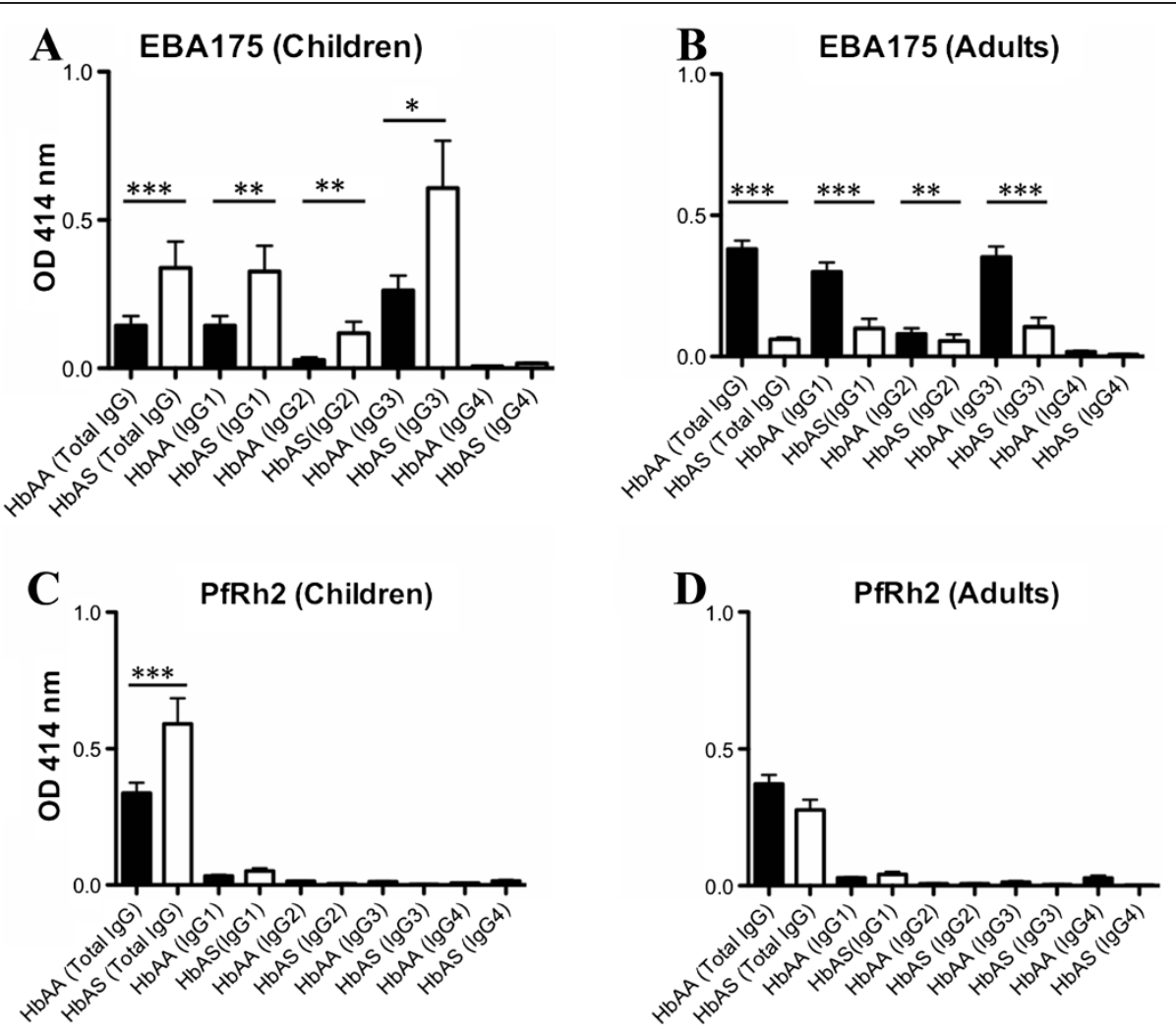

Figure 4 The total IgG and subclass levels to EBA175 (A, B) and PfRh2 (C, D) in HbAA and HbAS for children $(n=18)$ and adults $(n=22)$ are shown; the number of samples $=\mathbf{3 0 2}$. The bars show mean \pm SEM of OD at $414 \mathrm{~nm}$. $\left.{ }^{*}, p<0.05 ;{ }^{* *}, p<0.01 ;{ }^{* * *}, p<0.001\right)$.

HbAS in children and adults living in Igbo-Ora, a rural area of Nigeria, over a period of almost one year. These antigens were chosen because they are potential vaccine candidates, and they use different invasion pathways. EBA175 uses a sialic acid (SA)-dependent invasion pathway with glycophorin A as its main receptor. PfRh2 plays a role in SA-independent invasion (with an as yet

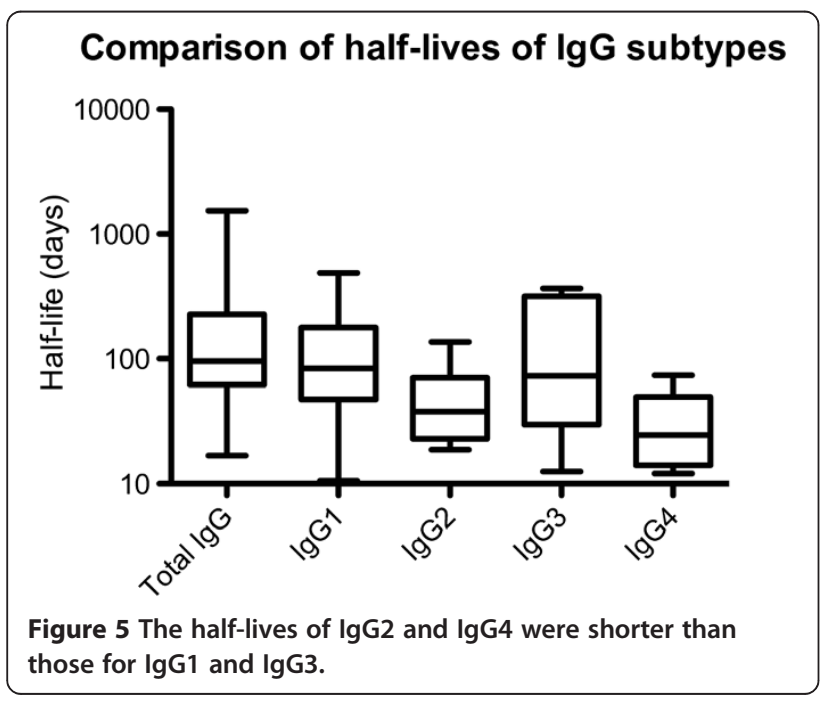

unknown receptor 'Z') [4], but some data suggest PfRh2 can also bind SA on the erythrocyte surface $[45,46]$. The EBAs and PfRhs play a vital role in merozoite invasion [47]. It has been suggested that a vaccine could be more efficient if antigens from different invasion pathways are used $[38,48]$, and it is therefore of interest to study the combined response in individuals who have acquired immunity by natural exposure to the $P$. falciparum parasite. Very few studies have investigated the subclass response to merozoite antigens over time.

The response for each subclass approximately followed the pattern of total IgG for both EBA175 and PfRh2, with a peak in antibody levels arising just after the peak in parasitaemia. This goes in line with the transmission intensity being highest during the rainy season, which ends in October. IgG1, IgG2 and IgG3 for EBA175 were positively associated with lower parasitaemias, indicating that all of these antibodies are possibly important for protection against malaria. These findings are in line with earlier studies that showed high levels of IgG, including IgG1 and IgG3 to EBA175, to be associated with protection from malaria $[19,49,50]$. Individuals with high levels of both total IgG against EBA175 and PfRh2 had a lower parasitaemia compared to those that had high levels of only one of the antibodies. This observation of 
combined antibody responses against two antigens underlines the importance of using combinations of antigens in vaccine trials $[38,48]$. When results from male and female individual were analysed, they were often slightly higher levels of antibodies in women. The reason for this is not clear, perhaps it is because of slightly different exposure.

In the studies that have been done before, looking at subclass responses against merozoite antigens, the responses have been dominated by IgG1 and IgG3 [19-21,25,42,51-53]. However, in this study, there was some response against both IgG2 and IgG4. IgG1 and IgG3 are considered cytophilic $[23,51]$ but in malaria non-cytophilic antibodies could also be of major importance. Even though the levels are low, the quality of the antibodies might be of more importance [54]. A study showed that high levels of IgG2 against RESA and MSP2 were associated with a lower risk of infection, indicating that IgG2 may be important, while IgG4 was suggested to block the cytophilic activity [22]. IgG4 has also before been shown to be of doubtful effect, in the response against MSP1-19, and it is especially interesting since this study was done in the same area of Nigeria as this study [55]. Omosun et al. [55] found dominating IgG1 and IgG3 responses to MSP1-19. While both IgG2 and IgG4 against MSP1-19 correlated positively with age, there was also a positive correlation of parasite density with IgG2 and IgG4 levels. Even though relatively high levels of IgG4 (especially against PfRh2) was found, there was no protective effect of this subclass when associated with parasitaemia. In an earlier study of subclass responses in children against PfRh2, mostly IgG1 and IgG3 were seen [42]. The reason for why the results from this study are slightly different might be because the population is different (Papua New Guinea compared to Nigeria), but also because all ages were included in this study. To elucidate whether IgG4 is protective or actually counter-acting protection, further studies are needed, but this study indicates that more subclass analysis should be included in studies of immunity in malaria.

For EBA175, IgG2 and IgG4 showed significantly shorter half-lives compared to IgG1 and IgG3. This is interesting since the half-life of IgG3 is normally considered to be considerably shorter than the other subclasses [56]. The short half-life noted here for IgG2 and IgG4 might help in explaining why IgG1 and IgG3 are often considered the most important ones in protection against malaria. It was also noted that parasite positive individuals had longer half-lifes of their IgG for both EBA175 and PfRh2, compared to individuals who were parasite negative all throughout the study period, which makes sense since the parasite positive individuals are exposed to parasites under a longer time period.
In this Nigerian population, the response in general towards EBA175 seemed stronger than against PfRh2. The subclass IgG1-IgG4 response against PfRh2 was low in this group. It has been shown before [45] that the expression of PfRh2 can vary between parasites, and it is not known which parasites were circulating in the area at the time. It might be that the recombinant antigen of EBA175 was more similar to the circulating parasites than the version of PfRh2 that was used. The results might also vary depending on which part of the protein was used. Region III-V of EBA175 was used in this study [19], and previous studies suggest that antibodies to region II of this protein have a lower protective association [13]. Antibodies to EBA and PfRh invasion ligands are thought to act primarily by inhibiting erythrocyte invasion, and studies have shown that vaccine-induced antibodies in animal studies [57,58], and in humans for EBA175 [41,59], can inhibit parasite growth in vitro. In previous studies of Kenyan children and adults, there has been evidence for that EBA175 and other EBAs, and PfRh invasion ligands are important targets of inhibitory antibodies, and variation in the function of these ligands can facilitate evasion of inhibitory antiobodies [41,54]. Recent studies have also demonstrated that affinitypurified human antibodies to EBA175, PfRh2, PfRh4, and PfRh5 can effectively inhibit invasion in vitro [59-62]. As a continuation of the studies in this paper, there are plans to compare invasion inhibition results to the subclass responses to elucidate whether any of the IgG subclasses could be more inhibitory than others.

When individuals with different haemoglobin were compared, there were different responses in children and adults, with higher levels of antibodies for HbAS in children. Children with HbAS had significantly higher levels of IgG, IgG1-3 against EBA175, and higher IgG levels against PfRh2. For adults the pattern was the opposite with higher IgG and IgG1-3 levels against EBA175, and higher IgG against PfRh2 in HbAA. It has been suggested before that the haemoglobin can affect the antibody response in malaria, but then the discussion has mainly concerned surface molecules on the erythrocyte $[63,64]$. Previous studies in Nigeria [65] and in other African countries $[30,66,67]$ have shown lower parasite densities as well as lower prevalence of both uncomplicated and severe malaria in individuals with HbAS compared to HbAA. Even though this study is based on a relatively small number of samples, the results indicate that further studies on differences between HbAS and HbAA individuals should be done for merozoite antigens and not only erythrocyte surface antigens.

\section{Conclusions}

Subclasses of IgG against both EBA175 and PfRh2 could be protective against malaria since they correlated with a 
lower parasitaemia. There were shorter half-lives of IgG2 and IgG4 against EBA175, which might explain why these subclasses are usually considered to be less important in protection against malaria. In evaluation of vaccine studies it might be important also to consider haemoglobin polymorphisms in different populations, especially in an area where HbAS is relatively common.

\section{Competing interests}

The authors declare that they have no competing interests.

\section{Authors' contributions}

$\mathrm{KP}$ and HAI planned the experiments, HAI and MKT performed the experiments, MKT and RN were responsible for the collection of patient samples, CL, LR and JGB supplied recombinant proteins, MTW performed the half-life analysis, JGB and MW took part in discussion of the project. All authors read and approved the final manuscript.

\section{Acknowledgements}

We thank the individuals of Igbo-Ora for their participation in the study. This work was supported by the Multilateral Initiative on Malaria (MIM) project A60143 through UNICEF/UNDP/WORLD Bank WHO Special Programme for Research and training in Tropical Disease (TDR), and the National Health and Medical Research Council of Australia, Wenner-Gren Fellow Stipend, Myndigheten för Samhällsskydd och Beredskap, Svenska Läkaresällskapet, Sida and Vetenskapsrådet.

\section{Author details}

'Department of Microbiology, Tumor and Cell Biology (MTC), Karolinska Institutet, Nobels väg 16, 17177 Stockholm, Sweden. ${ }^{2}$ Cellular Parasitology Programme, Cell Biology and Genetics Unit, Department of Zoology, University of Ibadan, Ibadan, Nigeria. ${ }^{3}$ The Macfarlane Burnet Institute for Medical Research and Public Health, Melbourne, VIC, Australia. ${ }^{4}$ Department of Infectious Disease Epidemiology, Imperial College, London, UK. ${ }^{5}$ Department of Laboratory Medicine, Lund University, University Hospital, Lund, Sweden.

Received: 9 July 2014 Accepted: 25 October 2014 Published: 5 November 2014

\section{References}

1. Snow RW, Guerra CA, Noor AM, Myint HY, Hay SI: The global distribution of clinical episodes of Plasmodium falciparum malaria. Nature 2005, 434:214-217.

2. WHO: World Malaria Report 2010. Geneva: World Health Organization; 2010

3. Talisuna AO, Karema C, Ogutu B, Juma E, Logedi J, Nyandigisi A, Mulenga M, Mbacham WF, Roper C, Guerin PJ, D'Alessandro U, Snow RW: Mitigating the threat of artemisinin resistance in Africa: improvement of drug-resistance surveillance and response systems. Lancet Infect Dis 2012, 12:888-896.

4. Cowman AF, Crabb BS: Invasion of red blood cells by malaria parasites. Cell 2006, 124:755-766.

5. Gaur D, Mayer DC, Miller LH: Parasite ligand-host receptor interactions during invasion of erythrocytes by Plasmodium merozoites. Int $\mathrm{J}$ Parasitol 2004, 34:1413-1429.

6. Baum J, Maier AG, Good RT, Simpson KM, Cowman AF: Invasion by P. falciparum merozoites suggests a hierarchy of molecular interactions. PLoS Pathog 2005, 1:e37.

7. Sim BK, Chitnis CE, Wasniowska K, Hadley TJ, Miller LH: Receptor and ligand domains for invasion of erythrocytes by Plasmodium falciparum. Science 1994, 264:1941-1944.

8. Stubbs J, Simpson KM, Triglia T, Plouffe D, Tonkin CJ, Duraisingh MT, Maier $A G$, Cowman AF, Winzeler EA: Molecular mechanism for switching of $P$. falciparum invasion pathways into human erythrocytes. Science 2005, 309:1384-1387.

9. Triglia T, Thompson J, Caruana SR, Delorenzi M, Speed T, Cowman AF: Identification of proteins from Plasmodium falciparum that are homologous to reticulocyte binding proteins in Plasmodium vivax. Infect Immun 2001, 69:1084-1092.

10. Duraisingh MT, Maier AG, Triglia T, Cowman AF: Erythrocyte-binding antigen 175 mediates invasion in Plasmodium falciparum utilizing sialic acid-dependent and -independent pathways. Proc Natl Acad Sci U S A 2003, 100:4796-4801.

11. Pasvol G: How many pathways for invasion of the red blood cell by the malaria parasite? Trends Parasitol 2003, 19:430-432.

12. Doolan DL, Dobano C, Baird JK: Acquired immunity to malaria. Clin Microbiol Rev 2009, 22:13-36

13. Fowkes FJ, Richards JS, Simpson JA, Beeson JG: The relationship between anti-merozoite antibodies and incidence of Plasmodium falciparum malaria: A systematic review and meta-analysis. PLoS Med 2010, 7:e1000218.

14. Langhorne J, Ndungu FM, Sponaas AM, Marsh K: Immunity to malaria: more questions than answers. Nat Immunol 2008, 9:725-732.

15. White MT, Griffin JT, Akpogheneta O, Conway DJ, Koram KA, Riley EM, Ghani AC: Dynamics of the antibody response to Plasmodium falciparum infection in African children. J Infect Dis 2014, 201:1115-1122.

16. Drakeley CJ, Corran PH, Coleman PG, Tongren JE, McDonald SL, Carneiro I, Malima R, Lusingu J, Manjurano A, Nkya WM, Lemnge MM, Cox J, Reyburn $H$, Riley EM: Estimating medium- and long-term trends in malaria transmission by using serological markers of malaria exposure. Proc Natl Acad Sci U S A 2005, 102:5108-5113.

17. Cohen S, McGregor IA, Carrington SC: Gamma-globulin and acquired immunity to human malaria. Nature 1961, 192:733-737.

18. Polley SD, Conway DJ, Cavanagh DR, McBride JS, Lowe BS, Williams TN, Mwangi TW, Marsh K: High levels of serum antibodies to merozoite surface protein 2 of Plasmodium falciparum are associated with reduced risk of clinical malaria in coastal Kenya. Vaccine 2006, 24:4233-4246.

19. Richards JS, Stanisic DI, Fowkes FJ, Tavul L, Dabod E, Thompson JK, Kumar S, Chitnis CE, Narum DL, Michon P, Siba PM, Cowman AF, Mueller I, Beeson JG: Association between naturally acquired antibodies to erythrocytebinding antigens of Plasmodium falciparum and protection from malaria and high-density parasitemia. Clin Infect Dis 2010, 51:e50-e60.

20. Roussilhon C, Oeuvray C, Muller-Graf C, Tall A, Rogier C, Trape JF, Theisen M, Balde A, Perignon JL, Druilhe P: Long-term clinical protection from falciparum malaria is strongly associated with $\lg \mathrm{G} 3$ antibodies to merozoite surface protein 3. PLoS Med 2007, 4:e320.

21. Stanisic DI, Richards JS, McCallum FJ, Michon P, King CL, Schoepflin S, Gilson PR, Murphy VJ, Anders RF, Mueller I, Beeson JG: Immunoglobulin G subclass-specific responses against Plasmodium falciparum merozoite antigens are associated with control of parasitemia and protection from symptomatic illness. Infect Immun 2009, 77:1165-1174.

22. Aucan C, Traore Y, Tall F, Nacro B, Traore-Leroux T, Fumoux F, Rihet P: High immunoglobulin G2 (lgG2) and low lgG4 levels are associated with human resistance to Plasmodium falciparum malaria. Infect Immun 2000, 68:1252-1258.

23. Bouharoun-Tayoun H, Attanath P, Sabchareon A, Chongsuphajaisiddhi T, Druilhe P: Antibodies that protect humans against Plasmodium falciparum blood stages do not on their own inhibit parasite growth and invasion in vitro, but act in cooperation with monocytes. J Exp Med 1990, 172:1633-1641.

24. Bouharoun-Tayoun H, Oeuvray C, Lunel F, Druilhe P: Mechanisms underlying the monocyte-mediated antibody-dependent killing of Plasmodium falciparum asexual blood stages. J Exp Med 1995, 182:409-418.

25. Mewono L, Matondo Maya DW, Matsiegui PB, Agnandji ST, Kendjo E, Barondi F, Issifou S, Kremsner PG, Mavoungou E: Interleukin-21 is associated with $\lg G 1$ and $\lg G 3$ antibodies to erythrocyte-binding antigen-175 peptide 4 of Plasmodium falciparum in Gabonese children with acute falciparum malaria. Eur Cytokine Netw 2008, 19:30-36.

26. Shi YP, Udhayakumar V, Oloo AJ, Nahlen BL, Lal AA: Differential effect and interaction of monocytes, hyperimmune sera, and immunoglobulin $\mathrm{G}$ on the growth of asexual stage Plasmodium falciparum parasites. Am J Trop Med Hyg 1999, 60:135-141.

27. Tebo AE, Kremsner PG, Luty AJ: Plasmodium falciparum: a major role for $\lg \mathrm{G} 3$ in antibody-dependent monocyte-mediated cellular inhibition of parasite growth in vitro. Exp Parasitol 2001, 98:20-28.

28. Kwiatkowski DP, Luoni G: Host genetic factors in resistance and susceptibility to malaria. Parassitologia 2006, 48:450-467.

29. Williams TN: Human red blood cell polymorphisms and malaria. Curr Opin Microb 2006, 9:388-394

30. Williams TN, Mwangi TW, Roberts DJ, Alexander ND, Weatherall DJ, Wambua S, Kortok M, Snow RW, Marsh K: An immune basis for malaria protection by the sickle cell trait. PLoS Med 2005, 2:e128.

31. Allison AC: Protection afforded by sickle-cell trait against subtertian malareal infection. Br Med J 1954, 1:290-294. 
32. Hill AV, Allsopp CE, Kwiatkowski D, Anstey NM, Twumasi P, Rowe PA, Bennett S, Brewster D, McMichael AJ, Greenwood BM: Common west African HLA antigens are associated with protection from severe malaria. Nature 1991, 352:595-600.

33. Taylor SM, Parobek CM, Fairhurst RM: Haemoglobinopathies and the clinical epidemiology of malaria: a systematic review and meta-analysis. Lancet Infect Dis 2012, 12:457-468.

34. Crompton PD, Traore B, Kayentao K, Doumbo S, Ongoiba A, Diakite SAS, Krause MA, Doumtabe D, Kone Y, Weiss G, Huang CY, Doumbia S, Guindo A, Fairhurst RM, Miller LH, Pierce SK, Doumbo OK: Sickle cell trait is associated with a delayed onset of malaria: Implications for time-to-event analysis in clinical studies of malaria. J Infect Dis 2008, 198:1265-1275.

35. Gong L, Maiteki-Sebuguzi C, Rosenthal PJ, Hubbard AE, Drakeley CJ, Dorsey $G$, Greenhouse B: Evidence for both innate and acquired mechanisms of protection from Plasmodium falciparum in children with sickle cell trait. Blood 2012, 119:3808-3814

36. Kreuels B, Kreuzberg C, Kobbe R, Ayim-Akonor M, Apiah-Thompson P, Thompson B, Ehmen C, Adjei S, Langefeld I, Adjei O, May J: Differing effects of $\mathrm{HbS}$ and $\mathrm{HbC}$ traits on uncomplicated falciparum malaria, anemia, and child growth. Blood 2010, 115:4551-4558.

37. Cholera R, Brittain NJ, Gillrie MR, Lopera-Mesa TM, Diakite SA, Arie T, Krause MA, Guindo A, Tubman A, Fujioka H, Diallo DA, Doumbo OK, Ho M, Wellems TE, Fairhurst RM: Impaired cytoadherence of Plasmodium falciparum-infected erythrocytes containing sickle hemoglobin. Proc Natl Acad Sci U S A 2008, 105:991-996.

38. Lopaticki S, Maier AG, Thompson J, Wilson DW, Tham WH, Triglia T, Gout A Speed TP, Beeson JG, Healer J, Cowman AF: Reticulocyte and erythrocyte binding-like proteins function cooperatively in invasion of human erythrocytes by malaria parasites. Infect Immun 2011, 79:1107-1117.

39. Ohas EA, Adams JH, Waitumbi JN, Orago AS, Barbosa A, Lanar DE, Stoute JA: Measurement of antibody levels against region II of the erythrocytebinding antigen 175 of Plasmodium falciparum in an area of malaria holoendemicity in western Kenya. Infect Immun 2004, 72:735-741.

40. Okenu DMN, Riley EM, Bickle QD, Agomo PU, Barbosa A, Daugherty JR, Lanar DE, Conway DJ: Analysis of human antibodies to erythrocyte binding antigen 175 of Plasmodium falciparum. Infect Immun 2000, 68:5559-5566.

41. Persson KEM, McCallum FJ, Reiling L, Lister NA, Stubbs J, Cowman AF, Marsh K, Beeson JG: Variation in use of erythrocyte invasion pathways by Plasmodium falciparum mediates evasion of human inhibitory antibodies. J Clin Invest 2008, 118:342-351.

42. Reiling L, Richards JS, Fowkes FJ, Barry AE, Triglia T, Chokejindachai W, Michon P, Tavul L, Siba PM, Cowman AF, Mueller I, Beeson JG: Evidence that the erythrocyte invasion ligand $\mathrm{PfRh} 2$ is a target of protective immunity against Plasmodium falciparum malaria. J Immunol 2010, 185:6157-6167.

43. Noutcha MAE, Anumdu Cl: Entomological indices of Anopheles gambiae sensu lato at a rural community in south-west Nigeria. $J$ Vector Borne Dis 2009, 46:43-51.

44. Ahmed Ismail H, Ribacke U, Reiling L, Normark J, Egwang T, Kironde F, Beeson JG, Wahlgren M, Persson KE: Acquired antibodies to merozoite antigens in children from Uganda with uncomplicated or severe Plasmodium falciparum malaria. Clin Vaccine Immunol 2013, 20:1170-1180.

45. Duraisingh MT, Triglia T, Ralph SA, Rayner JC, Barnwell JW, MCFadden Gl, Cowman AF: Phenotypic variation of Plasmodium falciparum merozoite proteins directs receptor targeting for invasion of human erythrocytes. EMBO J 2003, 22:1047-1057.

46. Sahar T, Reddy KS, Bharadwaj M, Pandey AK, Singh S, Chitnis CE, Gaur D: Plasmodium falciparum reticulocyte binding-like homologue protein 2 $(\mathrm{PfRH} 2)$ is a key adhesive molecule involved in erythrocyte invasion. PLoS One 2011, 6:e17102.

47. Tham WH, Healer J, Cowman AF: Erythrocyte and reticulocyte binding-like proteins of Plasmodium falciparum. Trends Parasitol 2012, 28:23-30

48. Richards JS, Arumugam TU, Reiling L, Healer J, Hodder AN, Fowkes FJ, Cross N, Langer C, Takeo S, Uboldi AD, Thompson JK, Gilson PR, Coppel RL, Siba PM, King CL, Torii M, Chitnis CE, Narum DL, Mueller I, Crabb BS, Cowman AF, Tsuboi T, Beeson JG: Identification and prioritization of merozoite antigens as targets of protective human immunity to Plasmodium falciparum malaria for vaccine and biomarker development. J Immunol 2013, 191:795-809.

49. McCarra MB, Ayodo G, Sumba PO, Kazura JW, Moormann AM, Narum DL John CC: Antibodies to Plasmodium falciparum erythrocyte-binding antigen-175 are associated with protection from clinical malaria. Pediatr Infect Dis J 2011, 30:1037-1042.

50. Medeiros MM, Fotoran WL, dalla Martha RC, Katsuragawa TH, LH P d S, Wunderlich G: Natural antibody response to Plasmodium falciparum merozoite antigens MSP5, MSP9 and EBA175 is associated to clinical protection in the Brazilian Amazon. BMC Infect Dis 2013, 13:608.

51. Bouharoun-Tayoun $H$, Druilhe P: Plasmodium falciparum malaria: evidence for an isotype imbalance which may be responsible for delayed acquisition of protective immunity. Infect Immun 1992, 60:1473-1481.

52. Dobano C, Quelhas D, Quinto L, Puyol L, Serra-Casas E, Mayor A, Nhampossa T, Macete E, Aide P, Mandomando I, Sanz S, Puniya SK, Singh B, Gupta P, Bhattacharya A, Chauhan VS, Aponte JJ, Chitnis CE, Alonso PL, Menéndez C: Age-dependent IgG subclass responses to Plasmodium falciparum EBA-175 are differentially associated with incidence of malaria in Mozambican children. Clin Vaccine Immunol 2012, 19:157-166.

53. Toure FS, Deloron P, Migot-Nabias F: Analysis of human antibodies to erythrocyte binding antigen 175 peptide 4 of Plasmodium falciparum. Clin Med Res 2006, 4:1-6.

54. Persson KEM, Fowkes FJI, McCallum FJ, Gicheru N, Reiling L, Richards JS, Wilson DW, Lopaticki S, Cowman AF, Marsh K, Beeson JG: Erythrocytebinding antigens of Plasmodium falciparum are targets of human inhibitory antibodies and function to evade naturally acquired immunity. J Immunol 2013, 191:785-794.

55. Omosun YO, Anumudu Cl, Adoro S, Odaibo AB, Sodeinde O, Holder AA, Nwagwu M, Nwuba Rl: Variation in the relationship between anti-MSP-1 (19) antibody response and age in children infected with Plasmodium falciparum during the dry and rainy seasons. Acta Trop 2005, 95:233-247.

56. Morell A, Terry WD, Waldmann TA: Metabolic properties of IgG subclasses in man. J Clin Invest 1970, 49:673-680.

57. Narum DL, Haynes JD, Fuhrmann S, Moch K, Liang H, Hoffman SL, Sim BK: Antibodies against the Plasmodium falciparum receptor binding domain of EBA-175 block invasion pathways that do not involve sialic acids. Infect Immun 2000, 68:1964-1966.

58. Pandey KC, Singh S, Pattnaik P, Pillai CR, Pillai U, Lynn A, Jain SK, Chitnis CE: Bacterially expressed and refolded receptor binding domain of Plasmodium falciparum EBA-175 elicits invasion inhibitory antibodies. Mol Biochem Parasitol 2002, 123:23-33.

59. Badiane AS, Bei AK, Ahouidi AD, Patel SD, Salinas N, Ndiaye D, Sarr O, Ndir O, Tolia NH, Mboup S, Duraisingh MT: Inhibitory humoral responses to the Plasmodium falciparum vaccine candidate EBA-175 are independent of the erythrocyte invasion pathway. Clin Vaccine Immunol 2013, 20:1238-1245.

60. Patel SD, Ahouidi AD, Bei AK, Dieye TN, Mboup S, Harrison SC, Duraisingh MT: Plasmodium falciparum merozoite surface antigen, $\mathrm{PfRH} 5$, elicits detectable levels of invasion-inhibiting antibodies in humans. $J$ Infect Dis 2013, 208:1679-1687.

61. Reiling L, Richards JS, Fowkes FJ, Wilson DW, Chokejindachai W, Barry AE, Tham WH, Stubbs J, Langer C, Donelson J, Michon P, Tavul L, Crabb BS, Siba PM, Cowman AF, Mueller I, Beeson JG: The Plasmodium falciparum erythrocyte invasion ligand Pfrh4 as a Target of functional and protective human antibodies against malaria. PLOS One 2012, 7:e45253.

62. Tran TM, Ongoiba A, Coursen J, Crosnier C, Diouf A, Huang CY, Li S, Doumbo S, Doumtabe D, Kone Y, Bathily A, Dia S, Niangaly M, Dara C, Sangala J, Miller LH, Doumbo OK, Kayentao K, Long CA, Miura K, Wright GJ, Traore B, Crompton PD: Naturally acquired antibodies specific for Plasmodium falciparum reticulocyte-binding protein homologue 5 inhibit parasite growth and predict protection from malaria. J Infect Dis 2013, 209:789-798.

63. Cabrera G, Cot M, Migot-Nabias F, Kremsner PG, Deloron P, Luty AJF: The sickle cell trait is associated with enhanced immunoglobulin $\mathrm{G}$ antibody responses to Plasmodium falciparum variant surface antigens. J Infect Dis 2005, 191:1631-1638.

64. Diatta AM, Marrama L, Tall A, Trape JF, Dieye A, Garraud O, MercereauPuijalon O, Perraut R: Relationship of binding of immunoglobulin $\mathrm{G}$ to Plasmodium falciparum-infected erythrocytes with parasite endemicity and antibody responses to conserved antigen in immune individuals. Clin Diagn Lab Immunol 2004, 11:6-11.

65. Fleming AF, Storey J, Molineaux L, Iroko EA, Attai ED: Abnormal haemoglobins in the Sudan savanna of Nigeria. I. Prevalence of haemoglobins and relationships between sickle cell trait, malaria and survival. Ann Trop Med Parasitol 1979, 73:161-172.

66. Agarwal A, Guindo A, Cissoko Y, Taylor JG, Coulibaly D, Kone A, Kayentao K, Djimde A, Plowe CV, Doumbo O, Wellems TE, Diallo D: Hemoglobin C 
associated with protection from severe malaria in the Dogon of Mali, a West African population with a low prevalence of hemoglobin S. Blood 2000, 96:2358-2363.

67. Aidoo M, Terlouw DJ, Kolczak MS, McElroy PD, ter Kuile FO, Kariuki S,

Nahlen BL, Lal AA, Udhayakumar V: Protective effects of the sickle cell gene against malaria morbidity and mortality. Lancet 2002,

359:1311-1312.

doi:10.1186/1475-2875-13-425

Cite this article as: Ahmed Ismail et al: Subclass responses and their

half-lives for antibodies against EBA175 and PfRh2 in naturally acquired

immunity against Plasmodium falciparum malaria. Malaria Journal

2014 13:425.

\section{Submit your next manuscript to BioMed Central and take full advantage of:}

- Convenient online submission

- Thorough peer review

- No space constraints or color figure charges

- Immediate publication on acceptance

- Inclusion in PubMed, CAS, Scopus and Google Scholar

- Research which is freely available for redistribution 